$\square$ 繁 殖 学 $\square$ Full Paper

\title{
Ultrastructural Changes during Maturation and Cryopreservation of Follicular Oocytes of Antarctic Minke Whales (Balaenoptera bonaerensis)
} Masatsugu ASADA ${ }^{1,4)}$, Masafumi TETSUKA ${ }^{2)}$, Hajime ISHIKAWA ${ }^{3)}$, Seiji OHSUMI ${ }^{3)}$ and Yutaka FUKUI ${ }^{1)}$

1) Department of Food Production Science, Obihiro University of Agriculture and Veterinary Medicine, West 2-line, Inada-cho, Obihiro 080-8555, Japan

2) Department of Agricultural and Life Science, Obihiro University of Agriculture and Veterinary Medicine, West 2-line, Inada-cho, Obihiro 080-8555, Japan

3) The Institute of Cetacean Research, 4-5, Toyomi-cho, Tokyo 104-0055, Japan

4) Present address: National Livestock Breeding Center, Tottori Station, 14, Kotoura-cho, Toh-haku-gun, Tottori 689-2501, Japan

(2006 年 4 月 10 日受領, 2006 年 12 月 21 日採択)

\author{
南極海産クロミンククジラ卵母細胞の体外成熟および \\ 凍結過程における微細構造の変化 \\ 浅田正嗣 ${ }^{1,4)}$, 手塚雅文 ${ }^{2)}$, 石川 創 ${ }^{3)}$, 大隅清治 ${ }^{3)}$, 福井 豊 ${ }^{1)}$ \\ 1）帯広畜産大学食料生産科学講座 $=080-8555$ 北海道帯広市稲田町西 2 線 \\ 2）带広畜産大学家畜生命科学講座 $=080-8555$ 北海道帯広市稲田町西 2 線 \\ 3）日本鯨類研究所 $\bar{\top} 104-0055$ 東京都中央区豊海町 4-5 \\ 4）現所属：家畜改良センター鳥取牧場 † 689-2501 鳥取県東伯郡琴浦町大字出上 14
}

\begin{abstract}
Important information for cryopreservation and in vitro culture could be obtained through ultrastructural observation of minke whale oocytes. In the present study, transmission electron microscopy was used to examine the ultrastructure of immature and in vitro mature Antarctic minke whale oocytes before and after freezing and thawing. Close communication existed between ooplasm and cumulus cell projections, and between mitochondria and membranous organelles, including the smooth endoplasmic reticulum in the ooplasm of minke whale immature oocytes. Cytoplasmic organelles, such as mitochondria and lipid droplets, were clustered in the ooplasm cortex region, while vesicles were located centrally in the ooplasm. After in vitro maturation, cytoplasmic organelles were observed to have distributed throughout the ooplasm, and the morphology of the mitochondria was changed. Cytoplasmic degeneration was observed in the minke whale oocytes after freezing and thawing. The slow freezing procedures employed in this study appeared to generate extensive and severe ultrastructural damages in minke whale ooplasms.

Key words: Balaenoptera bonaerensis, minke whale, oocyte, transmission electron microscopy (TEM)
\end{abstract}

Jpn. J.Zoo. Wildl. Med. 12(1): 51-60, 2007

\section{INTRODUCTION}

No information is available regarding details of the normal oocyte structure of large baleen whales. In a previous study [1], the ultrastructure of immature oocytes of minke whales after freezing and thawing was described. There are reports in cattle oocytes undergoing maturation that cytoplasmic organelles, such as mitochondria and cortical granules (CGs), exhibit specific patterns of reorganization and morphological changes [2-6]. Cytoplasmic organelle reorganization was a result of interrupted communication between oocytes and cumulus cells [5]. Cumulus cells form processes that traverse the zona-pellucida (ZP) and end in foot processes that penetrate into the oocyte cortex region, where they form gap junctions with oolemma $[7,8]$. These heterogeneous contacts are also important during final maturation in cattle oocytes [9]. Gap junctions as metabolic couplings are vital for normal oocyte growth and for maintenance of meiotic arrest in mouse oocytes [10].

It has been demonstrated through ultrastructural observations that cytoplasmic organelles in cryopreserved mammalian oocytes were impaired during freezing and thawing procedures. These include plasma membrane disruption $[11,12]$, release of CGs $[13,14]$, extensive ooplasm disorganization, and loss of oocyte-cumulus cell attachment [15]. Viability of immature (31-44\%) and in vitro mature (IVM; 49-69\%) minke whale oocytes has been reported to be low after freezing and thawing $[1,16]$. Observations by 
transmission electron microscopy suggested that low viability of minke whale oocytes after freezing and thawing might be due to rupture of the membranes of the ooplasm and vacuolation of mitochondria [1].

The purposes of the present study using Antarctic minke whales (Balaenoptera bonaerensis) were verification and comparison of fresh and frozen-thawed immature and IVM oocyte ultrastructures such as characteristics of microvilli, mitochondria, and cortical granules. If ultrastructural observation of Antarctic minke whale oocytes were possible, important information for cryopreservation [1] and in vitro culture $[17,18]$ of the whale oocytes could be obtained approaching the level of in vitro embryo production for other mammals, such as cattle and sheep.

\section{MATERIALS AND METHODS}

\section{Animals}

This study was undertaken as part of the 1999/2000 Japanese Whale Research Program under Special Permit in the Antarctic. The present research area comprised Area IV (60-68 $\mathrm{S}$ and $\left.70-130^{\circ} \mathrm{E}\right)$ and the eastern part of Area III $\left(58^{\circ} \mathrm{S}\right.$ to the ice edge and $35-70^{\circ} \mathrm{E}$ ) in the Antarctic Ocean; it was conducted from 5 December 1999 to 10 March 2000 [19]. All the whales used in the present study were killed by explosive harpoons which have been recognized by the IWC/SC as the most humane method to kill whales, and is accepted by schedule III (Capture) in the International Convention for the Regulations of Whaling. Special attention to reduce the time to death was given to all sampled whales; explosive harpoons for the primary method and the large caliber rifle as the secondary method when required. Whales were killed with grenaded harpoons according to the regulation of whaling under the International Convention.

\section{Oocyte Collection and In vitro Maturation}

Oocytes were collected from 34 female whales. Follicles (1-10 $\mathrm{mm}$ in diameter) were aspirated with an 18-gauge needle connected with a $10-\mathrm{ml}$ syringe containing a modified phosphate-buffered saline (mPBS: Embryo-Tech; NihonZenyaku Industrial, Japan) supplemented with $0.5 \%(\mathrm{v} / \mathrm{v})$ sodium citrate solution (Chitoramin; Fuso Pharmaceutical, Japan). Recovered follicular oocytes were selected as described by Fukui et al. [18]. Cumulus-oocyte complexes were washed three times with mPBS. The medium used for IVM was a Tissue Culture Medium 199 (TCM199; Gibco Life Technologies, USA) supplemented with $2 \mathrm{mM}$ L-glutamine, 50 $\mathrm{IU} / \mathrm{ml}$ penicillin, and $50 \mathrm{mg} / \mathrm{ml}$ streptomycin (all from Sigma Chemical, USA). The maturation medium contained $1 \mu \mathrm{g} / \mathrm{ml}$ estradiol-17 $\beta$ (Sigma), $0.01 \mathrm{mg} / \mathrm{ml}$ porcine pituitary follicle stimulating hormone (Antrin; Denka Pharmaceutical, Japan) and $20 \%(\mathrm{v} / \mathrm{v})$ fetal whale serum [17]. Follicular oocytes (5-30) were co-cultured with $5 \times 10^{5}$ live granulosa cells $/ \mathrm{ml}$ in a 4-well dish in $0.5 \mathrm{ml}$ of maturation medium covered with mineral oil (E.R. Squibb and Sons, USA) for $120 \mathrm{~h}[18,20]$ at $37^{\circ} \mathrm{C}$ in $5 \% \mathrm{CO}_{2}$ in air and $\leq 95 \%$ humidity. Every $48 \mathrm{~h}$ during culture, $0.3 \mathrm{ml}$ of maturation medium was replaced with fresh medium. Granulosa cells were collected at the time of aspiration of follicles and washed once ( $600 \mathrm{x}$ g for $10 \mathrm{~min}$ ) with the mPBS, and then washed twice with the TCM199 after being kept for $30 \mathrm{~min}$ at room temperature $\left(22-24^{\circ} \mathrm{C}\right)$. The supernatant was discarded after centrifugation; the granulosa cell pellet was suspended with TCM199.

\section{Freezing and Thawing}

Dulbecco's PBS (D-PBS: Nissui Pharmaceutical, Japan) containing $1.5 \mathrm{M} 10 \%(\mathrm{v} / \mathrm{v})$ ethylene glycol, $0.1 \mathrm{M}$ sucrose, and $10 \%(\mathrm{v} / \mathrm{v})$ heat-treated fetal calf serum (FCS) was used as a cryoprotective medium. Immature and IVM oocytes were transferred to the cryoprotective medium and equilibrated for $10 \mathrm{~min}$ at room temperature $\left(20-22^{\circ} \mathrm{C}\right)$. After equilibration, a group of 10 oocytes was loaded into a 0.25 -ml straw; the open end of the straw was plugged with polyvinyl alcohol powder, and the straw was then transferred into a pre-cooled methanol bath $\left(0^{\circ} \mathrm{C}\right)$ within a programmable freezer (ET-UM; Fujiya Yano Science, Japan). Straws were cooled from $0^{\circ} \mathrm{C}$ to $-6.5^{\circ} \mathrm{C}$ at $0.5^{\circ} \mathrm{C} / \mathrm{min}$, and then seeded at $-6.5^{\circ} \mathrm{C}$ for $10 \mathrm{~min}$. After seeding, straws were further cooled to $-35^{\circ} \mathrm{C}$ at the rate of $0.3^{\circ} \mathrm{C} / \mathrm{min}$ before they were plunged into liquid nitrogen $\left(\mathrm{LN}_{2}\right)$. Oocytes were kept in $\mathrm{LN}_{2}$ for 3-5 months prior to being thawed and subsequent experimentation. Straws were warmed rapidly (10 sec at $25^{\circ} \mathrm{C}$ in air, followed by $20 \mathrm{sec}$ at $37^{\circ} \mathrm{C}$ in a water bath), and cryoprotectants were removed by transferring oocytes directly into D-PBS supplemented with 10\% FCS [21].

Preparation of Oocytes for Transmission Electron Microscopy Fresh immature (Fig. 1A; $\mathrm{n}=10$ ) and IVM (Fig. 1C; $\mathrm{n}=5$ ) oocytes were pre-fixed by Karnovsky's solution ( $1 \%$ glutaraldehyde and $4 \%$ paraformaldehyde containing 0.1 M phosphate buffer [PB; pH 7.4]) on board the vessel. Karnovsky's solution was changed to a fresh solution every 1 month for 5-6 months. In the laboratory, fresh and frozenthawed [immature (Fig. 1B) : n=8; IVM (Fig. 1D) : n=4] oocytes were re-fixed by $2.5 \%$ glutaraldehyde in $0.1 \mathrm{M} \mathrm{PB}$ for 2 h at $4^{\circ} \mathrm{C}$, followed by $1 \%$ osmium tetraoxide in $0.1 \mathrm{M} \mathrm{PB}$ for 2 $\mathrm{h}$ at $4^{\circ} \mathrm{C}$ according to the procedures described previously for bovine oocytes $[22,23]$. Briefly, after routine dehydration with a graded series of ethanol, oocytes were infiltrated successively with $3: 1,1: 1$, and 1:3 mixtures of absolute propylene-oxide and Spurr's epoxy resin, and then with absolute Spurr's epoxy resin. Oocytes were embedded in beam capsules with fresh Spurr's epoxy resin. Ultrathin sections $(80 \mathrm{~nm}$ ) were cut with a diamond knife and double-stained with uranyl acetate and lead citrate; they were then examined under an H-7500 transmission electron microscope (Hitachi, Tokyo, Japan).

\section{RESULTS}

\section{Fresh Immature Oocytes}

Aggregation of membrane-bound vesicles and mitochondria 

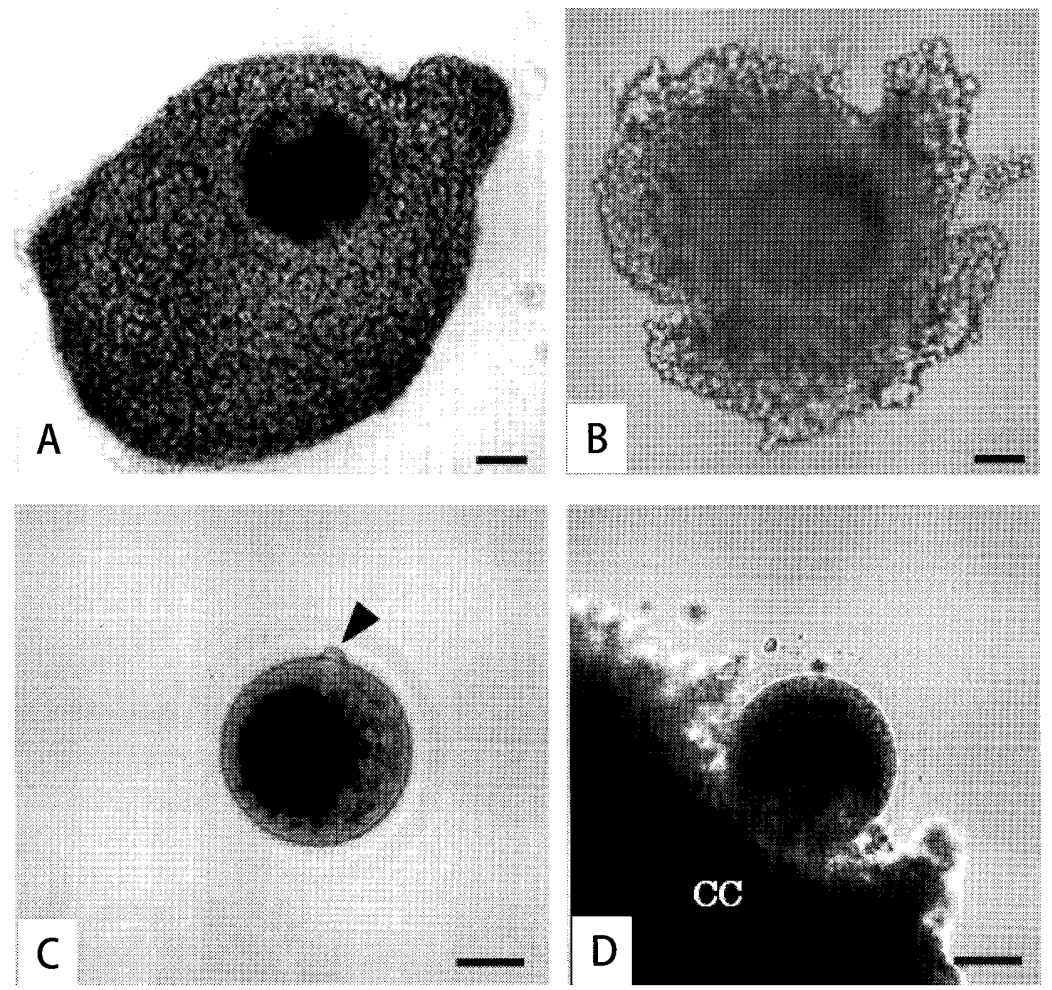

Fig.1 A: A COC with homogeneous cytoplasm and surrounded with numerous cumulus layers. B: A follicular oocyte after freezing and thawing. C: An in vitro matured oocyte with an extruded first polar body (arrowhead). D: An in vitro matured oocyte after freezing and thawing, which was partially surrounded with expanded cumulus cells (bar: $50 \mu \mathrm{m}$ ).

was observed in peripheral ooplasm (Figs. 2A, 3 and 4A). Central ooplasm was largely free from cytoplasmic organelles, and there were confluent vesicles (Fig. 2A). The cortical region of ooplasm was occupied by some coated vesicles (Fig. 3). Fresh oocytes and cumulus cells were tightly attached to the zona-pellucida (ZP; Fig. 2A). Cumulus cell processes into the oocyte were located in a perivitelline space with microvilli (Fig. 4A). Also, 2-3 $\mu \mathrm{m}$ diameter mitochondria (Fig. 6A), about $0.5 \mu \mathrm{m}$ diameter cortical granules (CGs), and Golgi apparatus were located in the ooplasm cortex region (Fig. 3). The most abundant form of endoplasmic reticulum appeared as smooth single sacs closely associated with outer surfaces of mitochondria, vesicles, Golgi apparatus, and lipid droplets in the ooplasm (Fig. 3). The smooth endoplasmic reticulum (SER) was closely associated with the mitochondria; these mitochondria occasionally possessed a "hood-like" process or appendage forming an extra mitochondrial cavity that often appeared to be intra-mitochondrial when the plane of the section passed through the hood (Fig. 6B). Fresh follicular oocytes had a multi-layered cumulus cell investment in which cells had well-developed cisternae of ER and Golgi apparatus (Fig. 7). Cumulus cells adjacent to the ZP showed numerous projections which penetrated through and finally attached to the oolemma (Fig. 4A).

\section{Fresh Oocytes after In vitro Maturation}

The oocytes after maturation had no deviations in specific organelle arrangements (Fig. 2B). A few cumulus projections were observed in the perivitelline space of an oocyte after maturation (Fig. 4C). Cytoplasmic organelles, homogeneous mass, lipid droplets, and vesicles were evenly intermixed and distributed throughout the ooplasm. Mitochondria of 3-7 $\mu \mathrm{m}$ in diameter after maturation culture were located in an even distribution in the ooplasm, and (Fig. 4C). After maturation, Golgi apparatus, SER, and lipid droplets became small in size, and vesicles tended toward more homogenous distribution (Fig. 4C vs A). CGs were dispersed in a lining beneath the cytoplasmic membrane (Fig. 4C). Mitochondria were intermixed with the more developed SER and Golgi apparatus (Fig. 4C), and showed numerous transverse criste (Fig. 6E). Figure $4 \mathrm{C}$ shows heterogeneous density of the ZP layer outer and inner surfaces. The outer ZP was rough compared to the inner surface. 

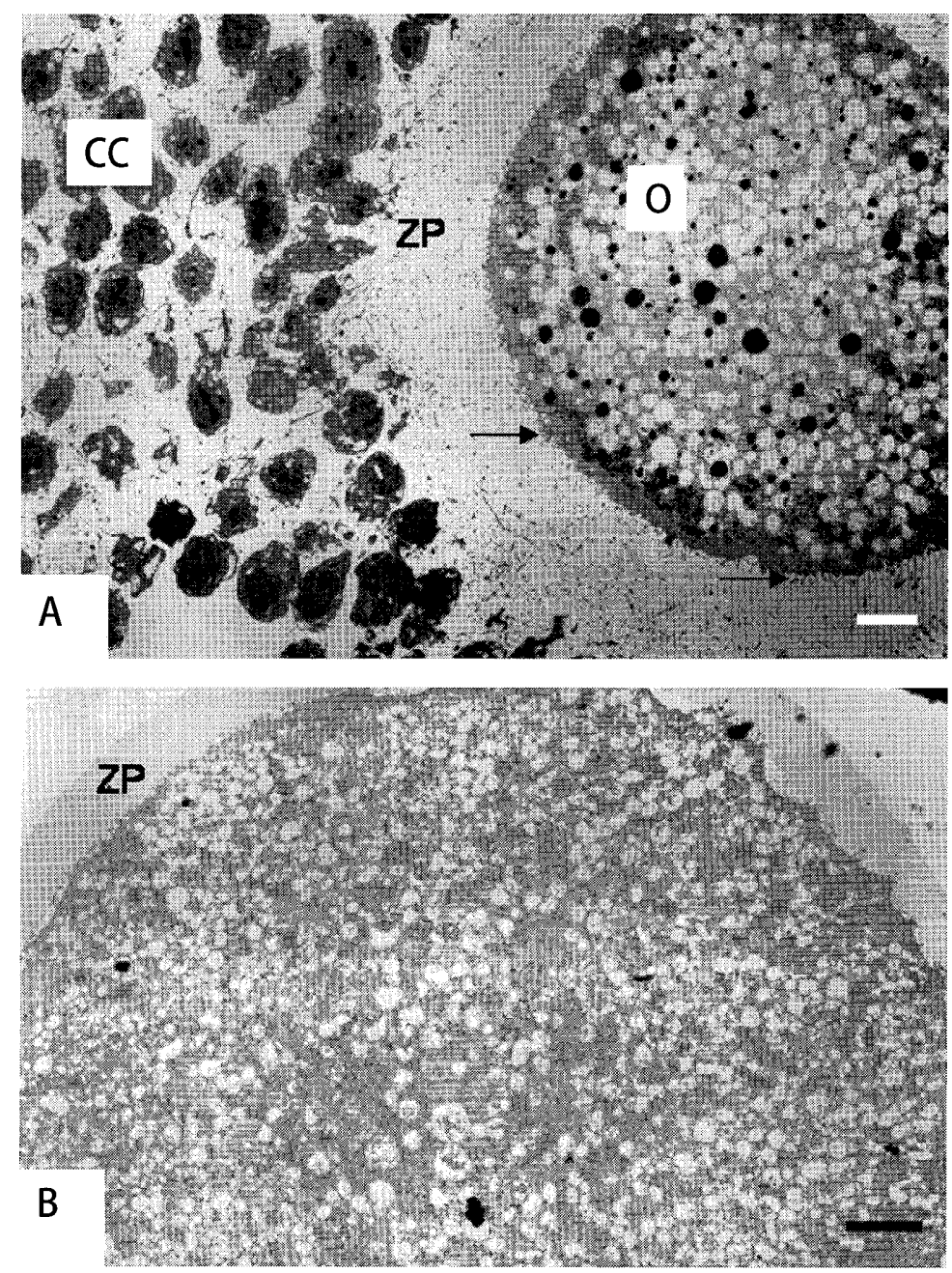

Fig.2 A: A whole structure of a fresh immature oocyte surrounded with cumulus cells (CC), zona-pellucida (ZP), and ooplasm $(\mathrm{O})$. Many vesicles were located in the center of the ooplasm, and the clusters of organelles under the oolemma were observed. Numerous microvilli (arrow) were well developed. B: A fresh oocyte cultured for in vitro maturation. Cumulus cells surrounding an oocyte were not shown. (bar: $10 \mu \mathrm{m}$ )

\section{Cryopreserved Oocytes}

Electron microscopy revealed widespread damage in cryopreserved immature and IVM oocytes, such as ooplasm membrane rupture (Fig. 4B), different structure microvilli vacuolation (Fig. 4B), disappeared CGs (Fig. 5) and presence of swollen ER (Fig. 5) and vacuolated mitochondria (Fig. 6D). After freezing and thawing, vacuoles were found to be present at the periphery of the oocytes (Figs. 4B and D). Microvilli in frozen-thawed immature oocytes exhibited degeneration and detachment of foot processes; they were also distorted or even absent (Fig. 4B). Numerous vesicles in abnormal oocytes appeared to migrate peripherally in the ooplasm, became confluent, and occasionally resulted in rupture of the oolemma (Figs. 4B and D). It was shown that the mitochondrial matrix becomes hollow in both frozen-thawed immature and IVM oocytes (Figs. 6C and D). Cumulus cells surrounding an immature oocyte after freezing and thawing displayed more vesicles than those of a fresh oocyte. (Fig. 7B vs A).

\section{DISCUSSION}

The present study, using immature and IVM oocytes of minke whales, attempted to clarify ultrastructural aspects. In addition, cytoplasmic organelle changes were shown after in vitro oocyte maturation, and freezing and thawing procedures. 
Ultrastructure of Minke Whale Oocytes

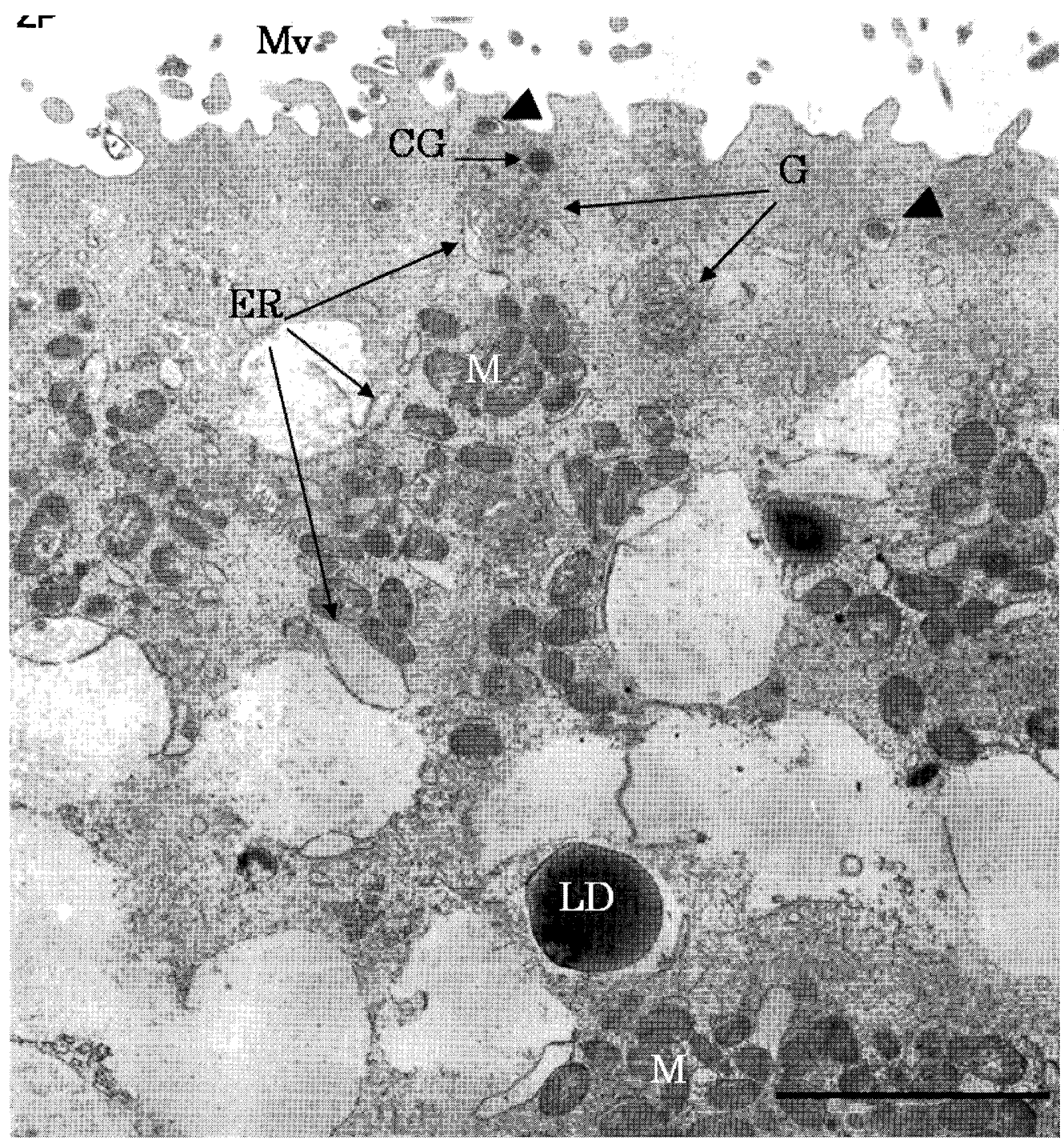

Fig. 3 The various organelles were shown in cortical region of a minke whale immature oocyte. The cortical granule (CG) and transport coated vesicles (arrowhead) in an endocytic pathway were located beneath oolemma. The dilated sacs of endoplasmic reticulum (ER) were surrounded with Golgi apparatus $(\mathrm{G})$ and mitochondria (M) (ZP: zona-pellucida, LD: lipid droplet). (bar: $5 \mu \mathrm{m}$ )

It has been reported that various cytoplasmic organelles appear in cumulus-oocyte complexes of human and domestic animals $[4,24,25]$. Also, the close association among mitochondria, vesicles and lipid droplets through SER in the oocyte has confirmed descriptions reported for cattle [3,5]

It is well known that cumulus cells play a very important metabolic role during follicular growth or IVM, supplying nutrients or other substances for oocyte development $[4,26,27]$. It was shown that numerous microvilli in the fresh immature oocytes intermediated with connection between cumulus cell projections (Figs. $2 \mathrm{~A}, 3$ and $4 \mathrm{~A}$ ). In contrast, cumulus cell projections disappeared in the ZP and perivitelline space after maturation (Fig. 4C). Therefore, close communication of ooplasm and cumulus cells would no longer be essential after oocyte maturation. In immature oocytes, vesicles appeared under lipid droplets and a mitochondria mass (Fig. 3). However, after IVM, vesicles were dispersed and smaller than in a follicular oocyte (Fig. 4C). It is reasonable to infer that vesicle contents were consumed during oocyte maturation because it is likely that the coated vesicles were caused by endocytosis or exocytosis occurring on the surface or inside oocytes (Fig. 3). Also, some mitochondria had a curved appendage consisting of both inner and outer membranes forming a "hood-like" structure (Fig. 6B). 

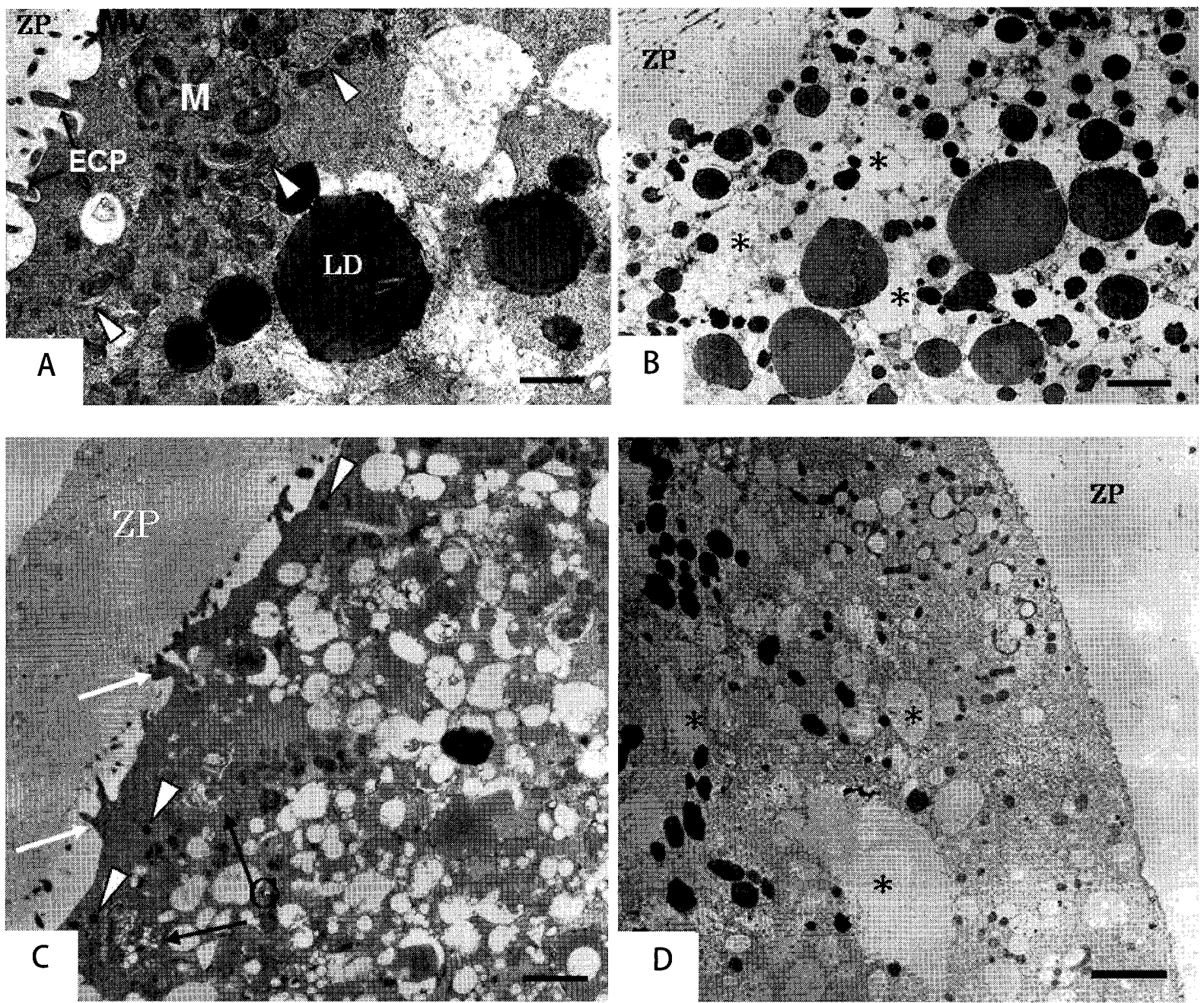

Fig. 4 A: A fresh immature oocyte. Clusters of mitochondria (M), and sacs of smooth endoplasmic reticulum (arrowhead) were observed between the mitochondria. Microvilli (Mv) were attached at the end point of cumulus cell projection (ECP) (LD: lipid droplet). B: Vesicles $\left(^{*}\right)$ were swollen in the oolemma in an immature oocyte after freezing and thawing. $\mathrm{C}$ : A fresh in vitro maturing oocyte. A few microvillus (white arrow) was shown on the smooth membrane. The cortical granules (arrowhead) were placed in parallel to an ooplasm membrane, and Golgi apparatus $(G)$ were also shown. D: The circumstance of oolemma in a frozen-thawed oocyte after in vitro maturation. Vesicles ${ }^{*}$ ) were swollen. (bar: $5 \mu \mathrm{m}$ )

"Hood-like" mitochondria structures were observed as reported in bovine and human oocytes [24,28]. In mature human oocytes, mitochondria are often observed to locate on the endoplasmic reticulum side with a mass of numerous transverse cristae, and are either elongated or transformed into "dumb-bell" shapes [25]. Rieger et al. [29] suggested that the relative effects of some cellular growth factors on the oocyte pyruvate metabolism generally correlated with cleavage and subsequent development. It was shown clearly that mitochondria were elongated and had multiple-layered cristae in minke whale oocytes after IVM (Fig. 6E). Thus, morphological change of mitochondria is considered to show functional characteristics during oocyte maturation. Furthermore, CGs after oocyte maturation culture migrate to individual positions forming a line along the oolemma. CGs were also observed under the oolemma in mature bovine oocytes $[4,28]$. The present observations revealed that CGs also appeared beneath the cytoplasm membrane after oocyte maturation (Fig. 4C). Probably, CGs release their contents into the perivitelline space when minke whale oocytes have been stimulated by fertilization or activation as fertilization events in other mammals. On the other hand, cytoplasmic organelles including mitochondrial clusters and vesicles were reorganized in bovine oocytes more than $19 \mathrm{~h}$ after LH surge [5]. It seems 


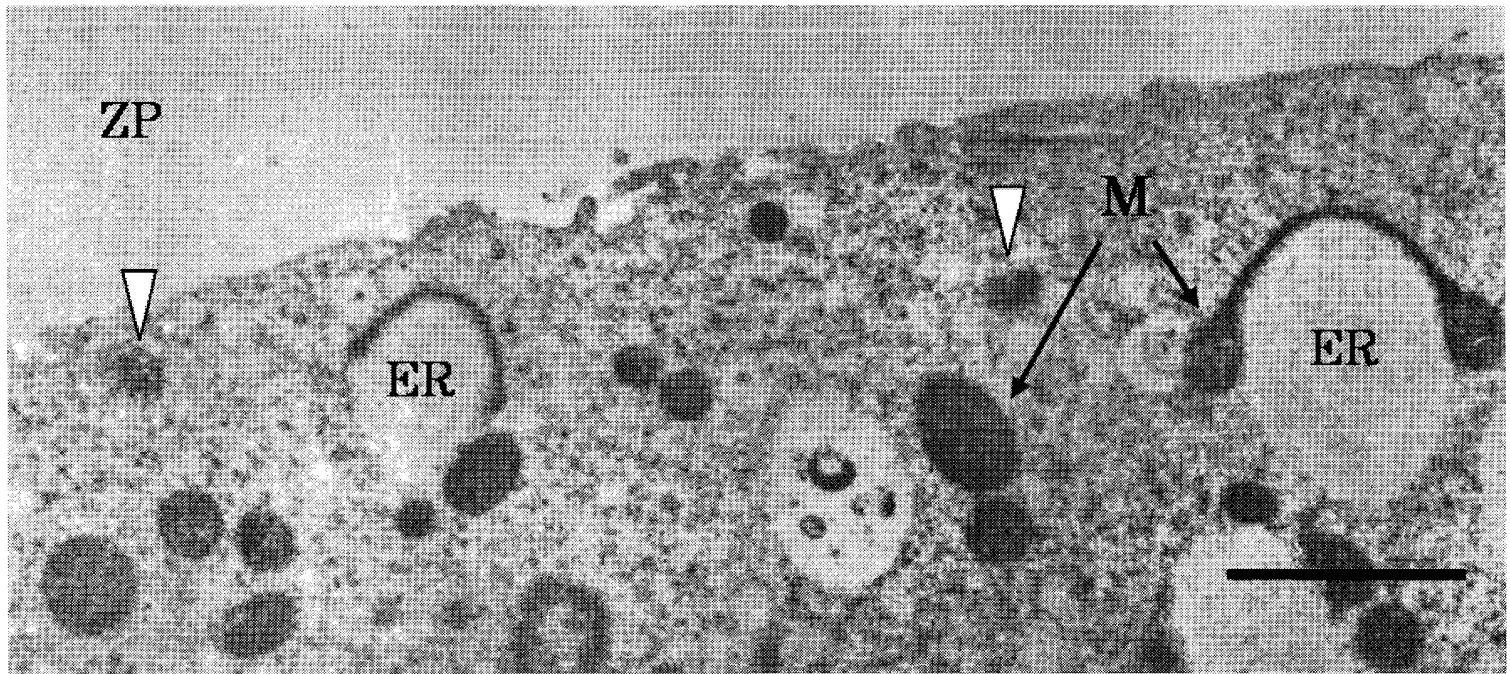

Fig. 5 The periplasm of a frozen-thawed oocyte cultured after in vitro maturation was shown. A part of cortical granules was indistinctness (arrowhead). The characteristic morphology of mitochondria (M) and swollen endoplasmic reticulum (ER) attached with them were shown. (ZP: zona-pellucida) (bar: $5 \mu \mathrm{m})$

that cytoplasmic organelles in minke whale oocytes become rearranged and ultrastructurally change during maturation. For example, mitochondrial elongation was shown as described in reports of bovine [4] and human [24] oocytes after IVM. These observations suggested that metabolic function occurred in cytoplasmic organelles during maturation in minke whale oocytes.

During freezing and thawing, mammarian oocytes have been damaged by various factors, including cryoprotectant toxicity, chilling injury, osmotic swelling, and shrinkage [13,14,30-33]. Electron microscopy of frozen-thawed minke whale oocytes showed the various damage to cytoplasmic organelles that is normally associated with freezing and thawing procedures. The survival rate $(40 \%)$ [16] in post-thawed minke whale oocytes was lower than those reported in other studies [34-37]. Observations of cryopreserved bovine [3] and mouse [14] oocytes showed that gathering vesicles often occupied the ooplasm and that the ooplasm was then ruptured. This vesicle confluence and plasma membrane destruction (Fig. 4B) in minke whale oocytes were also observed in the present study. This phenomenon was recognized during oocyte shrinkage at the time of freezing; increased vacuolation resulted from shrinking and changes in cellular volume. Osmotic change of cytoplasm volume probably caused membrane rupture and broken organelles. Also, it can be speculated that breakdown in contact of cumulus cell projections to the ooplasm and loss of mitochondrial integrity were consequences of osmotic shock; an oocyte seemed to appear first in change of these membranous structures by freezing and thawing.

Microvilli loss indicates close coupling between the oocyte and its investment of cumulus cells [38]. Disappearance of cumulus cell projections hinders nutrient transportation to minke whale oocytes. Therefore, it was considered that the oocytes, after freezing and thawing, would demonstrate lower proportions of survivability and maturation ability. For cryopreserved horse oocytes [15], the freezing method induces some ultrastructural changes such as mitochondria vacuolationed and, peripheral ooplasm destruction and communication. In the present study, the mitochondrial matrix in ooplasm of the fresh minke whale oocytes was quite highly density (Figs. 6A and E), whereas mitochondria swelling with reduced matrix density was observed in the frozenthawed oocytes (Figs. 6C and D). This observation implies that the vacuolated mitochondrial matrix was affected by the cryopreservation procedures. Changes in the ZP area associated with decreased CG number did not occur in isolated ZP from ooplasm [39]; also, it was suggested that effects of cooling and cryoprotective agents on the ZP lead to premature CG exocytosis and zona hardening [40]. In the present study using minke whale IVM oocytes after freezing and thawing, indistinct CGs (Fig. 5) might have been induced by low temperature and cryoprotectants during freezing and thawing as reported in cryopreserved bovine oocytes $[32,41]$. Cumulus cells surrounding oocytes (Fig. 7) were morphologically similar to bovine cumulus cells as reported by Zhao et al. [23]. However, vesicles in cumulus cells of minke whales were swollen after freezing and thawing, suggesting that cumulus cells were contracted by the cryoprotective medium.

Salient points of the present results are that minke whale immature oocytes had close communication between the ooplasm and cumulus cell projections, and between mitochondria and SER in the ooplasm. A cytoplasmic organelle mass including mitochondria and lipid droplets was located in the ooplasm cortex region. In addition, vesicles were evident 

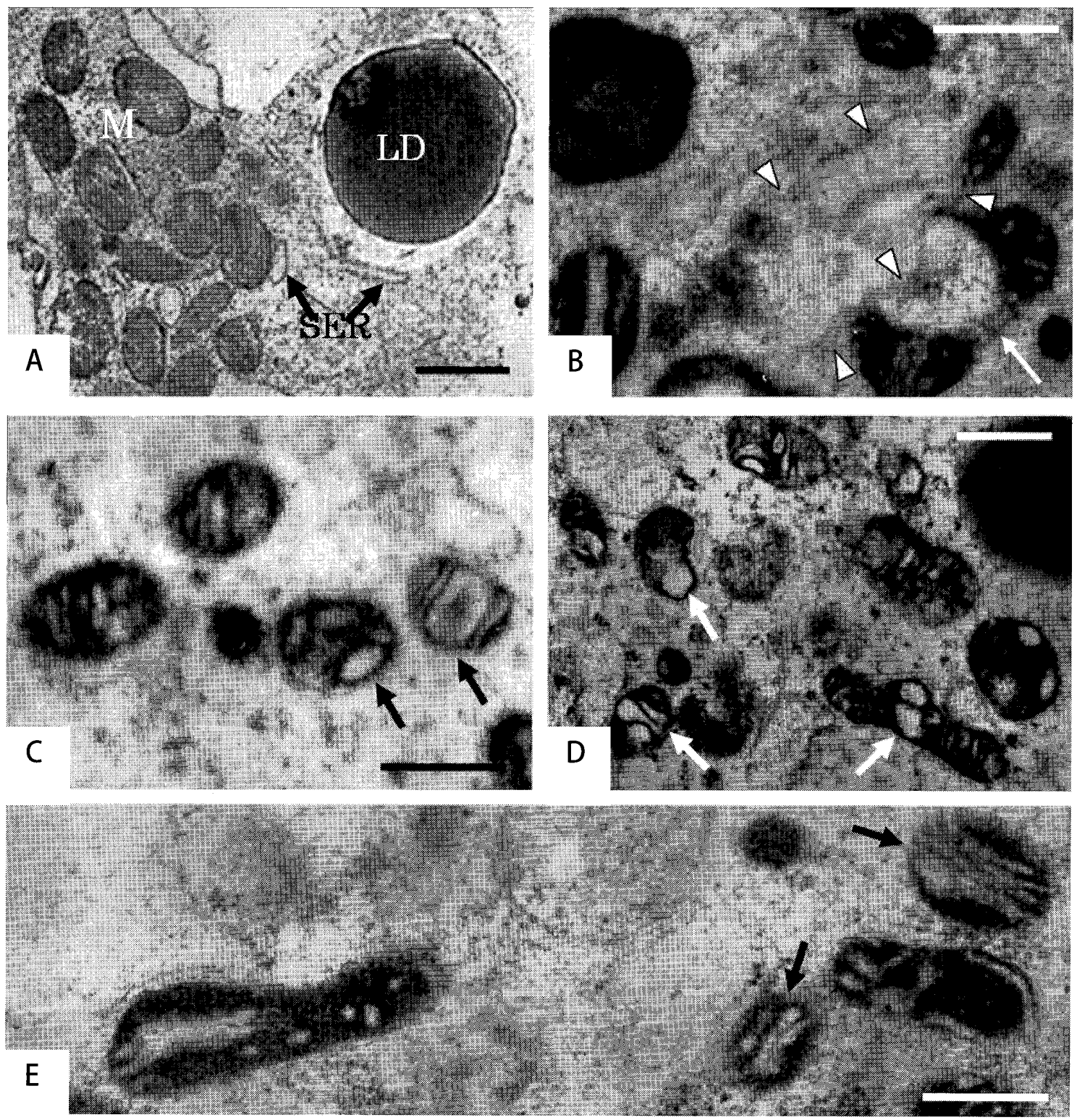

Fig. 6 A: The high matrix density in the ellipse shape of mitochondria (M) was attached with smooth endoplasmic reticulum (SER) and a lipid droplet (LD) in a fresh immature oocyte. B: The cavity of a "hood-like" mitochondorion (arrow) which was passed to the SER membrane (arrowhead) in a fresh immature oocyte. C: The matrix density of mitochondria was lowered in a frozen-thawed immature oocyte. D: The vacuolation of mitochodrial matrix was observed in a frozen-thawed oocyte after in vitro maturation. E: Numerous transverse cristae (arrow) into mitochondria was observed in a fresh IVM oocyte. (bar: $3 \mu \mathrm{m}$ )

within the central ooplasm in immature oocytes. Therefore, the ultrastructure of immature and in vitro maturing minke whale oocytes was quite similar to that reported in bovine oocytes. On the other hand, cytoplasmic organelles in whale oocytes after IVM were distributed homogeneously throughout the ooplasm; then mitochondria and SER changed morphologically. It is suggested that the cytoplasmic organelles of whale oocytes undergo functional changes during maturation. Regarding ultrastructural damages to cryopreserved minke whale oocytes, these observations were caused by the freezing and thawing procedures used in this study. Physical damage to oocytes was also present in both immature and IVM oocytes after cryopreservation. 
Ultrastructure of Minke Whale Oocytes
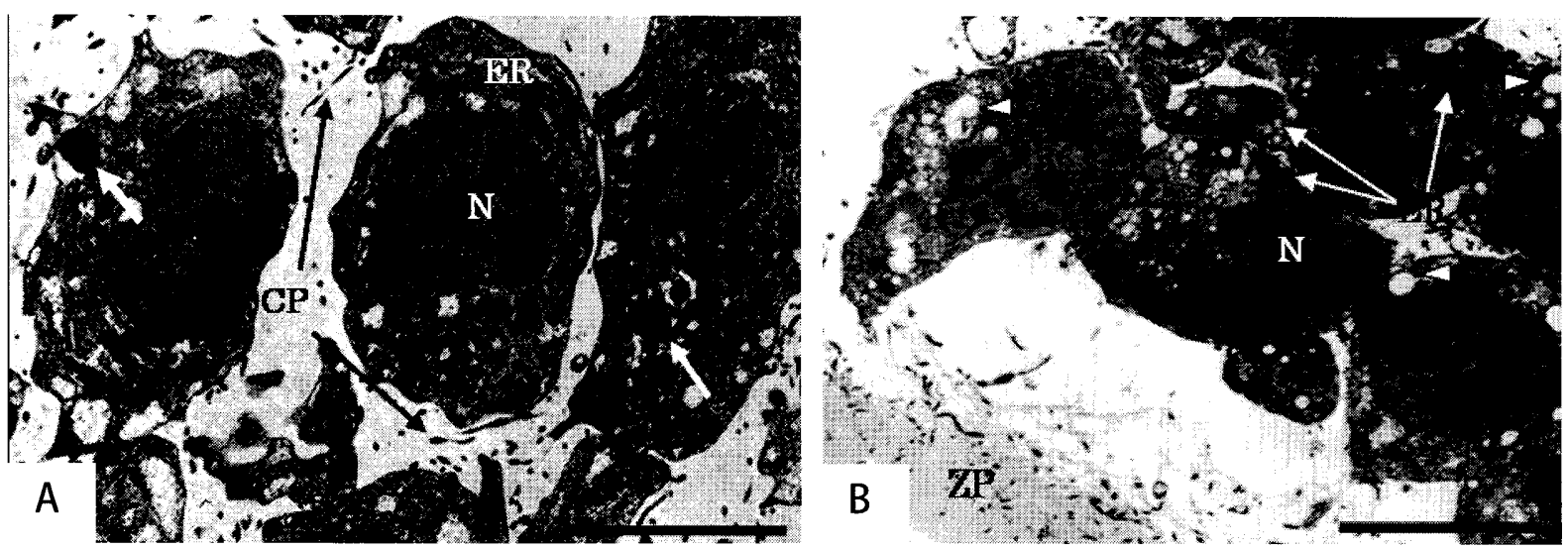

Fig. 7 A: Cumulus cells surrounding a fresh immature oocyte had a large decondensation of nuclei $(\mathrm{N})$ and lipid droplets (white arrow), and endoplasmic reticulum (ER) were extended to the many cytoplasmic projections (CP). B: Cumulus cells surrounding a frozen-thawed immature oocyte had the similar components with fresh cumulus cells. The swollen vesicles (arrowhead) were seen. (ZP: zona-pellucida) (bar: $5 \mu \mathrm{m}$ )

\section{ACKNOWLEDGEMENTS}

We are grateful to Captain D. Tohyama and the crew of the research base ship, Nisshin-maru, for their help in obtaining minke whales ovaries. We thank Dr. H. Furuoka, Associate Professor in the Laboratory of Veterinary Pathology, Obihiro University of Agriculture and Veterinary Medicine for his assistance with the transmission electron microscopic techniques.

\section{要 約}

超微細構造の観察を行うことによって, 卵母細胞の凍結保存 や体外培養のための重要な知見が得られる。本研究では, 透過 型電子顕微鏡を使用して, クロミンククジラ卵母細胞の体外成 熟の培養前後において, 凍結前および凍結・融解後の超微細構 造を観察した。成熟前の卵母細胞では, 卵細胞質と卵丘細胞突 起間に，また卵細胞質内のミトコンドリアや滑面小胞体を含む 細胞内小器官の間に緊密な接着部が存在していた。ミトコンド リアや脂肪滴のような卵細胞質内小器官は細胞質の辺縁で塊状 に分布していたが，小胞は細胞質の中心部に位置していた。体 外成熟後の新鮮卵母細胞では, 細胞質内小器官は細胞質内全体 に分布し，ミトコンドリアの形態に変化が見られた。凍結・融 解後の卵母細胞では, 卵細胞質の変性が観察され, 凍結・融解 過程において卵細胞質の微細構造に大きな障害が生じたことが 伺われた。

キーワード：卵母細胞, 凍結保存, 体外成熟, 細胞質, クロ ミンククジラ

\section{REFERENCES}

1. Asada M, Horii M, Mogoe T, Fukui Y, Ishikawa H, Ohsumi S. 2000. In vitro maturation and ultrastructural observation of cryopreserved minke whale (Balaenoptera acutorostrata) follicular oocytes. Biol Reprod 62: 253-259.

2. Familiari G, Verlengia C, Nottola SA, Tripodi A, Hyttel P, Macchiarelli G,
Motta PM. 1998. Ultrastructural features of bovine cumulus-corona cells surrounding oocytes, zygotes and early embryos. Reprod Fertil Dev 10: 315-326.

3. Fleming WN, Saacke RG. 1972. Fine structure of bovine oocytes from the mature graffian follicle. J Reprod Fertil 29: 203-213.

4. Hyttel P, Fair T, Avery B, Callesen H, Greve T. 1999. Transcriptional activity and ultrastructural in bovine oocytes. Reprod Domest Anim 34: 247-254.

5. Kruip TAM, Cran DG, Van Beneden TH, Dieleman SJ. 1983. Structural changes in bovine oocytes during final maturation in vivo. Gamete Res 8 : 29-47.

6. Shamsuddin M, Larsson B, Rodriguez-Martinez H. 1993. Maturationrelated changes in bovine oocytes under different culuture conditions. Anim Reprod Sci 31: 49-60.

7. Anderson E, Albertini, DF. 1976. Gap-junctions between the oocyte and companion follicle cells in the mammalian ovary. J Cell Biol 7 1: 680-686.

8. De Loos F, Kastrop P, Maurik VP, Kruip TAM. 1991. Heterologous cell contacts and metabolic coupling in bovine cumulus oocyte complexes. Mol Reprod Dev 28: 255-259.

9. Skoblina MN. 1988. Maturation of mammalian oocytes in vitro. In Oocyte Growth and Maturation (Detlaff TA, Vassetzky SG eds.), pp. 341-392. Plenum Publishing Cooperation, New York.

10. Brower PT, Schultz RM. 1981. Intracellular communication between granulosa cells and mouse oocytes: Existence and possible nutritional role during oocyte growth. Dev Biol 90: 144-153.

11. Eroglu A, Toner M, Leykin L, Toth TL. 1998. Cytoskeleton and polyploidy after maturation and fertilization of cryopreserved germinal vesicle stage mouse oocytes. J Assist Reprod Gen 15: 447-454.

12. Park SE, Son WY, Lee SH, Lee KA, Ko JJ, Cha KY. 1997. Chromosome and spindle configurations of human oocytes matured in vitro after cryopreservation at the germinal vesicle stage. Fertil Steril 68: 920-926.

13. Fuku E, Liu J, Downey BR. 1995. In vitro viability and ultrastructural changes in bovine oocytes treated with a vitrification solution. Mol Reprod Dev 40: 177-185 
14. Schalkoff M, Oskowitz S, Douglas PR. 1989. Ultrastructural observations of human and mouse oocytes treated with cryopreservatives. Biol Reprod 40: 379-393.

15. Hochi S, Kozawa M, Fujimoto T, Honda E, Yamada J, Oguri N. 1996. In vitro maturation and transmission electron microscopic observation of horse oocytes after vitrification. Cryobiology 33: 300-310

16. Asada M, Wei H, Nagayama R, Tetsuka M, Ishikawa H, Ohsumi S, Fukui Y. 2001. An attempt at intracytoplasmic sperm injection of frozen-thawed minke whale (Balaenoptera acutorostrata) oocytes. Zygote 9: 299-307.

17. Asada M, Tetsuka M, Ishikawa H, Ohsumi S, Fukui Y. 2001. Improvement on in vitro maturation, fertilization and development of minke whale (Balaenoptera acutorostrata) oocytes. Theriogenology 56: 521-533.

18. Fukui Y, Mogoe T, Ishikawa H, Ohsumi S. 1997. Factors affecting in vitro maturation of minke whale (Balaenoptera acutorostrata) follicular oocytes. Biol Reprod 56: 523-528.

19. Ishikawa H, Murase H, Tohyama D, Yuzu S, Otani S, Mogoe T, Masaki T, Kimura N, Ohshima T, Konagai T, Asada M, Takeuchi J, Kinoshita T. 2000. Cruise report of the Japanese Whale Research Program under Special Permit in the Antarctic (JARPA) Area IV and Eastern part of Area III in 1999/2000. In Document SC/52/020 presented to the 52nd IWC Scientific Committee, 25.

20. Fukui Y, Mogoe T, Ishikawa H, Ohsumi S. 1997. In vitro fertilization of in vitro matured minke whale (Balaenoptera acutorostrata) follicular oocytes. Marine Mammal Sci 13: 395-404.

21. Hochi S, Kanamori A, Sugisawa K, Kimura K, Hanada A. 1999. Effect of linoleic acid-albumin in the IVM and IVF media on survival of frozenthawed pronuclear bovine zygotes. J Mammal Ova Res 16: 19-22.

22. De Loos F, Maurik VP, Beneden VT, Kruip TAM. 1992. Structural aspects of bovine oocyte maturation in vitro. Mol Reprod Dev 31: 208-214.

23. Zhao J, Hattori M, Fujihara N. 1997. Ultrastructural comparison between immature and in vitro matured bovine oocytes cryopreserved in propanediol. J Mammal Ova Res 14: 84-94.

24. Gosden RG, Bownes M. 1995. Molecular and cellular aspects of oocyte development. In Gametes: the oocyte (Grudzinskas JG, Yovich JL eds.), pp. 23-53. Cambridge University Press, Cambridge.

25. Sathananthan AH. 2000. Ultrastructure of human gametes, fertilization, and embryo development. In Handbook of In Vitro Fertilization (Trounson AO, Gardner DK eds.), pp. 431-464. CRC Press, Florida.

26. Fukui Y, Sakuma Y. 1980. Maturation of bovine oocytes cultured in vitro in relation to ovarian activity, follicular size and the presence or absence of cumulus cells. Biol Reprod 22: 669-673.

27. Kim KS, Minami N, Yamada M, Utsumi K. 1996. Functional role of cumulus cells during maturation in development of in vitro matured and fertilized bovine oocytes. Theriogenology 45: 278 (abstract).

28. Hyttel P, Xu KP, Smith S, Greve T. 1986. Ultrastructure of in-vitro oocyte maturation in cattle. J Reprod Fertil 78: 615-625.

29. Rieger D, Luciano AM, Modina S, Pocar P, Lauria A, Gandolfi F. 1998. The effects of epidermal growth factor and insulin-like growth factor I on the metabolic activity, nuclear maturation and subsequent development of cattle oocytes in vitro. J Reprod Fertil 112: 123-130.

30. Arav A, Shehu D, Mattioli M. 1993. Osmotic and cytotoxic study of vitrification of immature bovine oocytes. J Reprod Fertil 99: 353-358.

31. Candy CJ, Wood MJ, Whittingham DG, Merriman JA, Choudhur N. 1994. Cryopreservation of immature mouse oocytes. Hum Reprod 9: 1738-1742.

32. Fuku E, Xia L, Downey BR. 1995. Ultrastructural changes in bovine oocytes cryopreserved by vitrification. Cryobiology 32: 139-156.

33. Vincent C, Garnier J, Heyman Y, Renard JP. 1989. Solvent effects on cytoskeletal organization and in-vivo survival after freezing of rabbit oocytes. J Reprod Fertil 87: 809-820.

34. Hochi S, Fujimoto T, Choi YH, Braun J, Oguri N. 1994. Cryopreservation of equine oocytes by 2-step freezing. Theriogenology 42: 1085-1094.

35. Pellicer A, Behrman HR, Lightman A, De Cherney AH, Parmer TG. 1998. Morphologic and functional studies of immature rat oocyte-cumulus complexes after cryopreservation. Fertil Steril 50: 805-810.

36. Schroeder AC, Champlin AK, Mobraaten LE, Eppig JJ. 1990. Developmental capacity of mouse oocytes cryopreserved before and after maturation in vitro. J Reprod Fertil 89: 43-50.

37. Yang QZ, Sun QY, Liu GY, Qin PC, Feng HL. 1994. Developmental competence and ultrastructure damage of cryopreserved GV-stage bovine oocytes. Theriogenology 41: 342 (abstract).

38. Hyttel P, Xu KP, Smith S, Greve T. 1986. Ultrastructure features of preovulatory oocyte maturation in superovulated cattle. J Reprod Fertil 76: 645-655.

39. Vincent C, Pickering SJ, Johnson MH. 1990. The zona hardening effect of dimethylsulphoxide on the mouse zona pellucida requires the presence of an oocyte and is associated with a reduction in the number of cortical granules present. J Reprod Fertil 89: 253-259.

40. Carroll J, Depypere H, Matthews CD. 1990. Freeze-thaw-induced changes of the zona-pellucida explains decreased rates of fertilization in frozen-thawed mouse oocytes. J Reprod Fertil 90: 547-553.

41. Hochi S, Kanamori A, Kimura K, Hanada A. 1997. In vitro fertilizing ability of bovine oocytes frozen-thawed at immature, maturing, and mature stage. J Mammal Ova Res 14: 61-65. 